\title{
KELAYAKAN PERANGKAT PEMBELAJARAN BAHASA INDONESIA BUATAN GURU MTS SWASTA PONTIANAK PADA MASA PANDEMI COVID-19
}

\author{
Khairullah, Antonius Totok Priyadi, Martono \\ Universitas OSO Pontianak \\ Email: khairullahhera25@gmail.com
}

\begin{abstract}
This study examined the feasibility of Indonesian learning tools made by teachers of private MTs Pontianak at the times of covid-19 pamdemic. Based on the results of the study, the teacher already made several good learning tools, however there were still shortcomings in certain components. The method used was descriptive qualitative research. The results of the study showed that the tools made by teachers of private MTs Pontianak that were good, there were lesson plan, teaching materials, learning media and evaluations (the questions made by teachers). However there will still some improvement needed in several components of the learning tools, such as school units, the core activity that were still the same from the first until the final meeting, and also the assessment rubric. Nevertheless, this study will alleviate teachers to prepare learning tools for the use of school accreditation, achieving school's vision and mission in the academic field and improving the quality of education in school.
\end{abstract}

\section{Keywords : Indonesian, Pontianak, The Feasibility of Learning Tools}

\section{PENDAHULUAN}

Perangkat adalah perlengkapan atau alat sedangkan pembelajaran adalah proses interaksi untuk memperoleh suatu informasi (belajar). Jadi perangkat pembelajaran adalah komponen yang harus disiapkan atau oleh guru sebelum melaksankan kegiatan belajar mengajar.

Zuhdan, dkk. (2011, p.16) berpendapat bahwa perangkat pembelajaran adalah perlengkapan yang disiapkan oleh pendidik untuk melaksanakan pembelajaran. Dalam melaksanakan pembelajaran, perangkat pembelajaran menjadi senjata yang digunakan oleh pendidik. Permendikbud No. 65 Tahun 2013 tentang Standar Proses Pendidikan Dasar dan Menengah menerangkan bahwa perangkat pembelajaran yang disusun oleh pendidik merupakan bagian dari perencanaan pembelajaran, yang berbentuk silabus dan RPP serta mengarah pada standar isi. Selain hal tersebut, penyipan media belajar, sumber belajar, perangkat penilaian, dan skenario pembelajaran dilakukan sebagai bagian perencanaan pembelajaran.

Pembelajaran mempunyai definisi sebagai proses korelasi yang terjalin antara peserta didik serta sumber belajar pada suatu zona belajar yang bertujuan untuk mendapatkan informasi. Pembelajaran merupakan suatu kegiatan yang menjadikan peserta didik sebagai manusia agar dapat bermanfaat bagi orang lain, sehingga pembelajarn tidak bisa dilepaskan dari dunia pendidikan. Dengan adanya pembelajaran yang dilakukan akan menjadi peserta didik sebagai insan yang berkarakter serta mampu bertanggung jawab di lingkungan sosial.

Satu di antara faktor yang mempengaruhi kualitas pembelajaran adalah variable guru. Guru mempunyai pengaruh yang cukup dominan terhadap kualitas pembelajaran, karena gurulah yang bertanggung jawab terhadap proses pembelajaran di kelas. Tuntutan-tuntutan tersebut mengharuskan seorang guru dapat mengembangkan kemampuan peserta didik 
agar terampil dalam berbahasa. Kemampuan berpikir yang sistematis, terkontrol, empiris dan kritis agar mencapai tujuan akhir yakni peserta didik terampil dalam berbahasa baik secara lisan maupun tulisan. Terampil berbahasa secara lisan berarti peserta didik dapat berbicara dengan baik dan benar, serta mudah dipahami oleh banyak orang sedangkan terampil dalam tulisan yakni perserta didik mampu menulis dengan kemampuan berbahasa menggunakan pilihan kata yang tepat dalam menyusun kaliamat secara efektif.

Proses pembelajaran secara daring atau yang dilakukan di rumah berpengaruh terhadap pembelajaran bahasa Indonesia. Pembelajaran bahasa Indonesia pada dasarnya merupakan pembelajaran yang diarahkan untuk meningkatkan kemampuan peserta didik dalam kegiatan berkomunikasi baik secara lisan maupun secara tulis. Selain itu, pembelajaran bahasa Indonesia dengan model pembelajaran yang tepat juga diharapkan dapat mengembangkan kemampuan berbahasa peserta didik, yaitu kemampuan mendengarkan, membaca, berbicara, dan menulis agar pembelajaran bahasa Indonesia dapat memenuhi fungsinya.

Penelitian ini dilakukan di sekolah Madrasah Thasawiyah Pontianak Kota. Berdasarkan hasil observasi yang dilaksanakn pada Februari 2021 terdapat Madrasah Thasanawiyah Negeri dan Swasta. Sekolah Madrasah Thsanawiyah di Pontianak kota ada 8 sekolah. Sekolah negeri terdiri dari Madrasah Thasanawiyah Negeri 1 Pontianak, dan MTs Negeri 2 Pontianak. Adapun sekolah MTs Swasta Pontianak Kota, terdapat 6 MTs Swasta di Pontianak Kota di antaranya ialah (1) MTs Swasta Darul Khairat, (2) MTs Swasta Darunna'im, (3) MTs IKA PGA, (4) MTs Swasta Mathla'ul Anwar (5) MTs Swasta Sirajul Ulum dan (6) MTs Swasta Wali Songo. Penelitian ini akan dilakukan di 3 sekolah Madrasah Thasanawiyah Swasta, (a) MTs Swasta Darul Khairat (b) MTs Swasta Sirajul Ulum dan (c) MTs Swasta Wali Songo.

Alasan peneliti memilih Madrasah Thsanawiyah Swasta pertama MTs Swasta yang berada di Pontianak kota merupakan MTs Swasta Darul Khairat memiliki akreditasi "A" sekolah yang mampu bersaing dengan sekolah favorit MTs Negeri 1 maupun 2 yang ada di Pontianak kota. Kedua MTs Swasta Pontianak kota merupakan sekolah yang berbasis agama serta penulis ingin mengetahui sejauh mana kurikulum 2013 diterapkan pada sekolah tersebut. Sedangkan sekolah MTs Swasta Wali Songo sekolah berbasis agama serta memiliki akreditasi "A". Sekolah Sirajul Ulum merupakan sekolah MTs Swasta yang berdiri pada tahun 2000-an tetapi jumlah peserta didik masih sangat sedikit fasilitas sekolah yang masih belum memadai, sekolah tersebut memiliki akreditasi "B". Beberapa hal tersebut peneliti memilih ketiga sekolah tersebut agar antara sekolah MTs Swasta Darul khairat, Wali Songo dan sirajul Ulum saling bertukar pikiran atau saling melengkapi. Selain itu penulis mendapat dukungan dan motivasi dari kepala sekolah beserta guru di MTS Swasta Pontianak kota sehingga mempermudah penulis dalam menghadapi kendala-kendala yang ada. Hal ini yang mendasari penulis tertarik melakukan penelitian yang berkaitan tentang kelayakan perangkat pembelajaran Bahasa Indonesia buatan guru MTS Swasta Pontianak kota pada masa pandemi covid-19.

Peraturan Menteri Pendidikan dan Kebudayaan Nomor 54 tahun 2013 menegaskan bahwa harapannya kepada SMP/Mts yang menerapkan kurikulum 2013 supaya bisa memproduksi lulusan yang berprilaku sebagai orang beriman, berilmu, percaya diri, berakhlak mulia, dan memiliki tanggung jawab ketika melakukan hubungan komunikasi secara efektif di lingkungan sekitarnya Kemudian dalam ranah pengetahuan, peserta didik diharapkan memiliki pengetahuan faktual, konseptual, dan prosedural dalam ilmu pengetahuan, teknologi, seni, dan budaya dengan wawasan kemanusiaan, kebangsaan, kenegaraan, dan peradaban terkait fenomena dan kejadian yang terlihat kemudian yang terakhir untuk ranah keterampilan, peserta didik diharapkan mampu berpikir dan bertindak dengan efektif 
dan kreatif sesuai dengan apa yang telah dipelajari di ssekolah baik secara abstrak maupun konkret. (Permendikbud, Nomor 54 tahun 2013 tentang Standar Kompetensi Lulusan (SKL).

Abidin (2016) berpendapat bahwa pembelajaran dengan konteks kurikulum 2013 minimal memiliki 5 model inti yaitu model proses saintifik, model integratif berdeferensiasi, model multiliterasi, model multisensor, dan model kooperatif. (p.112)

Nurdyansyah dan Fahyani (2016, p.11) menjelaskan bahwa pada kurikulum 2013 pembelajaran yang dilaksanakan adalah berbasis oendekatan ilmiah dan tematik integrative yang di dalamnya akan menempa peserta didik agar memiliki kompetensi yang lebih baik dalam bersikap, penguasaan keterampilan, dan ilmu pengetahuan.

Pembelajaran bahasa Indonesia yang terdapat di dalam kurikulum 2013 adalah pembelajaran berbasis teks. pembelajaran berbasis teks maksudnya pembelajaran dilakukan dengan menghubungkan suatu kebahasaan dengan struktur berpikir sebagai tujuan sosial teks, dan tidak dalam bentuk serpihan saja seperti dalam pendekatan struktural. Setiap teks dalam pembelajaran ini memilliki struktr yang berbeda, sehingga peserta didik akan mendapat ruang untuk mengembangkan struktur berpikirnya. Penguasaan struktur berfikir peserta didik akan semakin banyak jika diiringi dengan penguasaan banyak jenis teks pula (Mahsun, 2014, p.95).

Dalam kurikulum 2013, pembelajaran bahasa Indonesia adalah pembelajaran dengan tiga pendekatan yaitu pedagogi genre, saintifik, dan CLIL (content language integrated learning).

Peningkatan kualitas pendidikan nasional merupakan suatuk eniscayaan. Hal ini meningkatkan pada dasawarsa terkahir kasus amoral di Indonesia, hal ini mengidinkasikan bahwa kualitas pendidikan di Indonesia belum berhasil mewujudkan manusia Indonesia sebagaimana tujuan pendidikan nasional. Pemilihan kurikulum 2013 memiliki dasar kepada dua alasan pokok, seperti yang dikemukan oleh Badar
(2017, p.243) yaitu: (1) Kuriulum Tingkat Satuan Pendidikan (KTSP) yang memberi keleluasaan untuk guru membuat kurikulum sendiri secara mandiri, membuat hal tersebut menjadi hal yang kurang efektif. (2) tidak semua guru memiliki dan dibekali profesionalisme dalam menyusun kurikulum dan Perencanaan Pelaksanaan Pembelajaran sehingga ada akhirnya yang terjadi adalah kegiatan menyalin tanpa ada proses kreatif.

Pendekatan dari pembelajaran bahasa Indonesia adalah pendekatan saintifik. Pendekatan saintifik 5M (Mengamati, Mempertanyakan, Mengumpulkan Informasi, Menalar, dan Mengomunikasikan) digunakan untuk mendapatkan pengetahuan (KD-3). Pengembangan keterampilan (KD-4) dilanjutkan dengan langkah mengonstruksi terbimbing dan mengonstruksi mandiri. Pendekatan saintifik dalam pembelajaran disajikan sebagai berikut. (a) Mengamati, (b) menanya (c) mengumpulkan Informasi, (d) menalar dan (e) mengomunikasikan.

Menurut Djumingin dan Syamsudduha, (2016, p.143) Rencana Pelaksanaan Pembelajaran (RPP) adalah rencana yang manajemen dan tata caranya diimplementasikan untuk mencapai tujuan dari kompetensi dasar yang dikembangkan secara profesional untuk memberikan pemahaman yang lebih mendalam.

Badar (2017, p.257) memaparkan fungsi dari Rencana Pelaksanaan Pembelajaran antara lain: (a) pembelajaran yang dilaksanakan guru menjadi lebih mudah dan proses kegiatan pembelaran meningkat karena pembelajaran diterapkan secara terprogram, (b) guu mampu mempersiapkan situasi emosional yang ingin dibangun, suasana belajar menjadi menyenangkan, serta suasana terjalin baik karena peserta didik yang aktif. (c) guru mempunyai tumpuan pelaksanaan pembelajaran yang lebih terarah, efektif, dan efisien. Sebab itu, tumpuan atau acuan yang di susun sebaiknya flesibilitas.

Manurut Andi Prastowo (2012, p.28) bahan ajar adalah bahan-bahan atau susunan berasal dari berbagai sumber yang kemudian berhasil dikumpulkan hingga dibuat secara sistematis. Konsep pembelajaran dalam suatu 
pelaksanaan pembelajaran diatur dalam sebuah bahan ajar. Bahan ajar adalah alat yang dipakai oleh guru dalam kegiatan belajar mengajar, alat tersebut berupaba hantertulis maupun tidak tertulis yang disiapkan untuk peserta didik pada proses pembelajaran (Wajdi, 2020, p.127).

Bahan ajar merupakan satu di antara perangkat yang digunakan oleh guru dalam pembelajaran di kelas, bahan ajar ajar dibuat dari kompetensi dasar yang telah ditentukan oleh silabus. Berdasarkan dari kompetensi dasar menjadikan indikator-indikator pencapaian kompetensi belajar yang kemudian dijelaskan dan dijabarkan melalui materi ajar. Dalam memberikan materi ajar guru disarankan untuk tidak terpaku dari buku ajar yang dibuat oleh Dinas Pendidikan saja, guru dituntut dapat mengembangkan materi ajar yang sudah ada, baik dari kebudayaan lokal maupun dengan keadaan dilingkungan sekitar.

Materi ajar merupakan panduan atau pedoman yang digunakan guru ketika memberikan materi pembelajaran. Materi ajar yang berasal dari Kompetensi Dasar tersebut harus sesuai dengan rancangan pelaksanaan pembelajaran yang telah dibuat. Materi ajar yang baik juga harus menyesuaikan dengan kurikulum yang berlaku pada sekolah dan keadaan yang terjadi sehingga harus dilakukan beberapa penyesuaian agar materi tersebut juga layak untuk digunakan. Hasil penyesuaian dan dapat dikatakan layak dari Kompetensi Dasar dan Materi Ajar berpengaruh terhadap tujuan dan hasil belajar peserta didik.

Berdasarkan hakikatnya, karakteristik ilmu atau materi itu berbeda-beda. Menurut Tim Pengembang MKDP Kurikulum dan Pembelajaran (Fantoni dan Riyana, 2016, p.4) secara teoretis di dalam mata pelajaran terdapat beberapa sifat materi yaitu: fakta, konsep, prinsip, masalah, prosedur (keterampilan), dan sikap (nilai). Perbedaan sifat tersebut membuat proses pengajaran materi harus dilakukan dengan cara yang berbeda pula bergantung pada sifatnya.

Materi ajar dalam pembelajaran bahasa Indonesia materi yang dibuat oleh guru dengan memerhatikan kepentingan nasional dengan mengangkat kearifan lokal sekitar sekolah. Dengan memerhatikan kemampuan peserta didik serta minatnya agar pembelajaran yang dilakukan dapat meningkatkan kemampuan intelektual peserta didik. Materi juga merupakan bagian terpenting dalam kegiatan pembelajaran, dengan adanya materi kegiatan pembelajaran dapat berlangsung dengan baik.

Media Pembelajaran

Heinich, dkk (1982) perbendapat "Instructional Technology and Media for Learning" bahwa media sebagai alat dalam saluran komunikas. Kata "media" berasal dari bahasa Latin dan merupakan bentuk jamak dari kata "medium" yang secara harfiah berarti "perantara" yaitu perantara sumber pesan (a source) dengan penerima pesan (a receiver). Selanjutnya, media pembelajaran yang beragam memberikan pilihan kepada pengajar untuk menggunakan yang mana, dengan syarat media pembelajaran yang digunakan itu membawa pesan-pesan (messages) dalam rangka mencapai tujuan pembelajaran. Media pembelajaran yang digunakan untuk keperluan pembelajaran bisa juga disebut sebagai teknologi pembawa pesan.

Media pembelajaran juga disebut sebagai teknologi. Maksudnya adalah dalam media pembelajaran terdapat pesan-pesan yang digunakan pada proses pembelajaran untuk disampaikan. Selain itu, media pembelajaran juga bisa menjadi alat untuk memotivasi peserta didik untuk terus mengikuti pembelajaran, serta mampu mengefisienkan pembelajaran antara peserta didik dengan guru sehingga materi pembelajaran akan tersampaikan secara sistematis dan lebih efektif.

Stufflebeam, dkk (1971) mendefinisikan evaluasi sebagai "The process of delineating, obtaining, and providing useful information for judging decision alternatives". Artinya, evaluasi adalah sebagai proses memperoleh atau menyajikan informasi untuk merumuskan suatu alternatif keputusan. 
Sudjiono, (2005) menjelaskan bahwa kata "evaluasi" secara harfiah berasal dari kata "evaluation" dalam bahasa Inggris, yang artinya penilaian. Akar kata evaluation adalah value yang berarti nilai. Jadi istilah evaluasi merujuk pada suatu kegiatan atau proses untuk menentukan nilai dari sesuatu (Ahmad, 2015, p.4).

Evaluasi adalah proses tertata dan berkesinambungan yang digunakan untuk mengumpulkan, menggambarkan, mendefinisikan dan menerangkan informasi tentang suatu program agar dapat dimanfaatkan sebagai dasar membuat keputusan, menyusun kebijakan maupun menyusun program kedepan. Evaluasi diharapkan mampu menentukan standar penilaian yang telah ditetapkan kepada peserta didik, serta dapat membantu menentukan jalan pembelajaran dan bahan ajar yang digunakan.

Menurut Daryanto (2010, p.6-8) tujuan dari evaluasi dalam pembelajaran yang dilakukan di sekolah terdapat 4 tujuan Input, Output, Transformasi, UmpanBalik. Process evaluatin aims to indentify or predict mismatches between planning and implementaton, provide information for programmmatic decisions, and record and assess each activity.in the program implementation stage, the aspects evaluated are program socialization, tutor recruitment and student placement. Stufflebeam (2007, p.77). Chittenden (1994) secara simple mengklasifikasikan tujuan penilaian (assesment purpose) adalahuntuk (1) keeping track, (2) checking up, (3) finding-out, dan (4) summing-up. Keempat tujuan tersebut oleh Arifin (dalam Asrul dkk, 2015, p.12). Tujuan yang selanjutnya yaitu evaluasi, evaluasi yang akan dilakukan untuk mengukur kemampuan siswa dalam menggunakan bahasa Indonesia, maka penyusunan soal bahasa Indonesia harus disusun dengan keterampilan menggunakan bahasa Indonesia dan bukan soal menanyakan pengetahuan bahasa.

Evaluasi dalam pembelajaran pada penelitian ini merupakan soal yang dibuat oleh guru untuk memberikan tes kepada peserta didik, apakah jenis soal sudah sesaui dengan kompetensi inti, dan inikator pencapaian. Tes/soal yang dibuat oleh guru harus dirancang dengan ketarampilan dan pelatihan khusus. Tes/soal yang digunakan adalah sebagai umpan balik kepada peserta didik berdasarkan hasil pembelajaran yang dilakukan selama 1 bab. Bisa berbentuk ulangan harian, ataupun soal-soal latihan.

\section{METODE PENELITIAN}

Metode yang digunakan dalam penelitian ini adalah metode deskriptif. Metode deskriptif yang dimaksud adalah usaha untuk mendapatkan gambaran serta deskripsi yang jelas. Peneliti berperan sebagai pengamat dalam penelitian kelayakan perangkat pembelajaran buatan guru bahasa Indonesia MTs Swasta Pontianak kota. Metode penelitian menurut Sugiyono (2015, p.3) adalah cara ilmiah untuk mendapatkan data dengan tujuan dan kegunaan tertentu. kemudian apa yang terjadi dipaparkan dalam bentuk laporan.

Bentuk penelitian yang digunakan dalam penelitian ini adalah bentuk penelitian kualitatif yaitu pengumpulan data data deskriptif (kata-kata lisan, tulisan, dan perilaku subjek). Data yang ada dianalisis menggunakan berdasarkan jenis data penelitian. Pertama penggambaran/ pendeskripsian suatu konteks khusus alamiah dan dengan memanfaatkan berbagai metode alamiah dalam bentuk kata-kata dan bahasa. Cara kedua adalah dengan perhitungan angka-angka. Moleong (2017, p.6) berpendapat bahwa penelitian kualitatif adalah penelitian yang menghasilkan prosedur analisis yang tidak menggunakan prosedur analisis statistik atau cara kuantitatif lainnya.

Sumber data dalam penelitian ini adalah guru mata pelajaran Bahasa Indonesia di MTs Swasta Pontianak kota. Terdapat tiga sekolah yang menjadi sumber penelitian ini di anataranya ialah (1) MTs Swasta Darul Khairat, (2) MTs Swasta Sirajul Ulum, dan (3) MTs Swasta Wali Songo. Dalam hal ini sumber pemerolehan data dalam pembuatan perangkat pembelajaran Bahasa Indonesia 
selama masa pandemi covid-19. Data dalam penelitian ini yaitu hasil dari pengamatan terhadap perangkat pembelajaran berupa Rencana Pelaksanaan Pembelajaran, Materi ajar, media pembelajaran dan evaluasi (soal) pembelajaran yang dibuat oleh guru MTs Swasta Darul Khairat, Sirajul Ulum dan Wali Songo. Data menurut Syam (2011, p.84) adalah keterangan yang menjadi dasar kajian hingga sampai pada simpulan yang objektif.

\section{HASIL DAN PEMBAHASAN Hasil}

Hasil penelitian yang akan disajikan adalah kelayakan perangkat pembelajaran bahasa Indonesia buatan guru MTs Swasta Pontianak pada masa pandemi covid-19. Subjek dalam penelitian kelayakan perangkat pembelajaran yang dibuat oleh guru MTs Swasta Walisongo, Darul Khairat, dan guru MTs Swasta Sirajul Ulum. Objek dalam penelitian berupa rencana pelaksanaan pembelajaran, materi ajar, media ajar, dan soal yang dibuat oleh guru MTs Swasta Pontianak Kota.

Berdasarkan data-data yang dianalisis dan yang diperoleh dari sumber data, dapat diketahui bahwa kesesuaian rencana pelaksanaan pembelajaran setiap guru diambil 2 Rencana Pelaksanaan Pembelajaran (RPP). Rencana pelaksanaan pembelajaran mewarisi nilai luhur dan mengkreasikan puisi rakyat dan mengapresiasi dan mengkreasi fabel. Terdapat 6 dokumen RPP, 6 materi ajar, 5 media pembelajaran, dan 6 kumpulan soal yang diambil dari setiap sekolah.

\section{Pembahasan}

Berdasarkan hasil pengamatan atas rencana pembelajaran yang dibuat oleh guru MTs Swasta Walisongo, Darul Khairat, dan Sirajul Ulum sudah baik meskipun terdapat beberapa kekurangan tetapi kekurangan tersebuat tidak menjadi kendala bagi guru MTs Swasta Pontianak Kota dalam menerapakan rencana dalam pelaksanaan pembelajaran. Dalam pembuatan materi ajar, guru hanya terpaku kepada buku LKS adapun tambahan materi diambil dari media internet.
Seharusnya dalam pembuatan materi guru harus mengembangkan atau memberikan materi tambahan dari daerah lokal Kalimantan Barat. Sedangkan dalam pembuatan media pembelajaran guru membuat maedia Power Point dan ditemukan pada materi tertentu guru membuat media dikarenakan kekurangan alat dalam penyampaiannya di kelas. Alat evaluasi atau soal yang dibuat oleh guru merupakan soal uji kompetensi yang pembuatannya didasari kompetensi dasar, indikator dan tujuan, dan tujuan pembelajaran. Soal-soal yang dibuat bersifat HOTS (High Order Thinking Skill). Tetapi terdapat satu guru yang mengambil soal dari buku LKS, yang seharusnya guru membuat soal sendiri berdasarkan pada kompetensi dasar dan tujuan pembelajaran.

\section{SIMPULAN DAN SARAN Simpulan}

Secara keseluruhan berdasarkan fokus penelitian dan temuan setiap sekolah hasil analisis disajikan sesuai dengan urutan rumusan masalah sehingga kesimpulan terdiri dari empat pokok utama yang sudah dianalisis dengan menggunakan teori yang sudah ada pada Kajian Teori. Untuk lebih rinci, dapat ditarik kesimpulan sebagai berikut.

Rencana Pelaksanaan Pembelajaran Bahasa Indonesia yang dibuat oleh guru MTs Swasta Pontianak Kota terdiri dari 3 sekolah Wali Songo, Darul Khairat dan Sirajul Ulum dalam format masih menggunakan ketentuan RPP yang lama, bukan seperti sekolah yang lain terdapat sekolah menggunakan rencana pelaksanaan pembelajaran (RPP) format baru menggunakan RPP 1 lembar. Rencana pembelajaran yang dibuat oleh guru MTs Swasta Walisongo sudah baik dalam pembuatannya, dari identitas sekolah sampai dengan penilaian yang dibuat. Hanya saja guru MTs Swasta Walisongo tidak membuat rubrik penilaian sikap, karena dalam penialaian sikap juga termasuk dalam kategori penilaian terhadap peserta didik, dengan ada rubrik penilaian guru akan lebih 
mudah memberikan penilaian tersebuat dan data tersimpan dengan baik ketika suatu saat dibutuhkan data itu bisa langsung diambil atau dicek kembali. Rencana pelaksanaan yang dibuat oleh guru MTs Darul Khairat, masih terdapat kekurangan lengkap, pada komponen identitas sekolah guru tidak mencantukkan sekolah dan materi, pada kegiatan inti yang dibuat oleh guru masih tidak efektif dikarenakan langkah-langkah kegiatan yang dibuat dari pertemuan pertama sampai akhir sama. Seharusnya guru lebih memerhatikan dan memisahkan kegiatan yang akan dilakukan, dengan memisahkan atau membuat kegiatan yang berbeda sesuai dengan ketentuan KD maka tujuan pembelajaran akan tercapai.

Materi pembelajaran yang dibuat atau digunakan guru berdasarkan pada buku LKS peserta didik adapun materi lain yang guru buat diambil dari media yang lain di antaranya media internet. Guru tidak melakukan pengembangan materi ajar yang signifikan, seharusnya guru mengangkat puisi rakyat dan cerita fabel yang berasal dari daerah-daerah di Kalimantan Barat agar peserta didik memiliki gambaran dan dapat membayangkan dengan pembelajaran yang dilakukan. Guru telalu berfokus pada buku LKS peserta didik yang pembahasannya terlalu sederhana dan perlu sekali dikembangkan. Dengan mengembangkan materi ajar pembelajaran akan lebih baik dan peserta didik memiliki pengetahuan lebih luas.

Media pembelajaran yang digunakan oleh guru berupa Power Point dan Youtobe. Media yang digunakan guru sudah baik tetapi masih perlu pengembangan, tidak mesti hanya menggunakan media power Point dan youtobe, misalnya menggunakan media Powtoon, Sparcol Video Scribe dan media yang lain. Dengan menggunakan atau mengambangkan media pembelajaran yang lain, peserta didik akan lebih bersemangat mengikuti pembelajaran. Pengembangan ini perlu dilakukan karena sesuai dengan perkembangan zaman, dalam penggunaan media yang modern bukan hanya guru MTs Swasta Walisongo, Darul Khairat, dan Sirajul
Ulum saja melaikan semua sekolah yang melakukan kegaitan pembelajaran. Hal ini penting dilakukan agar tujuan pembelajaran tercapai dengan baik dan maksimal.

Alat evaluasi yang digunakan oleh guru berupa soal pilihan ganda, guru sudah membuat berdasarkan indikator dan tujuan pembelajaran ada juga guru yang mengambil dari buku LKS peserta didik. Evaluasi dilakukan untuk melakukan penilaian pengetahuan. Alat evaluasi yang digunakan guru tersebut belum sesuai untuk dapat mengevaluasi hasil belajar peserta didik pada masa pandemi covid-19. Masa pndemi covid19 ini menyebabkan guru sulit untuk melakukan proses evaluasi, namun dalam penggunaan alat evaluasi oleh guru MTs Swasta Pontianak kota (Wali Songo, Darul Kahirat, Sirajul Ulum). Adapun soal yang dibuat bersifat HOTS (Higher Order Thinking Skills).

\section{Saran}

Penelitian yang berjudul "Kelayakan Perangkat Pembelajaran Buatan Guru Bahasa Indonesia MTs Swasta Pontianak Kota pada Masa Pandemi Covid-19". Berdasarkan hasil observasi yang dilakukan oleh peneliti, guru harus lebih teliti dalam membuat perangkat pembelajaran memperhatikan komponenkomponen dalam menyusun rencana pelaksanaan pembelajaran, misalnya identitas sekolah harus ditulis, instrumen penilaian, dan komponen-komponen lain yang belum lengkap. Pembuatan materi ajar guru harus lebih mengembangkan materi yang sudah ada baik dibuku paket dan buku LKS, seharusnya guru memerhatikan indikator dan potensi daerah dalam pembuatan materi. Media ajar yang dibuat oleh guru hanya sebatas Power point, guru harus lebih kreatif dan inovatif agar peserta didik lebih termotivasi dengan pembelajaran yang lebih menarik. Guru membuat evaluasi (soal) harus memperhatikan keperaktisan keekonomisan dan lain sebagainya. Perangkat yang dibuat harus berdasarkan kurikulum 2013 berbasis teks. Kegiatan pembelajaran yang dilaksanakan pada masa pandemi harus menyesuaikan dengan waktu yang telah 
ditentukan agar kegiatan pembelajaran yang dilakukan bisa tersampaikan secara maksimal kepada peserta didik.

\section{DAFTAR RUJUKAN}

Abidin. (2016). Desain Sistem Pembelajaran dalam Konteks Kurikulum 2013. Bandung: PT RefikaAditama.

Ahmad. (2015). Buku Evaluasi Pembelajaran. Yogyakarta: Interpena Yogyakarta.

Andi. (2012). Panduan Kreatif Membuat Bahan Ajar yang Inovatif. Yogyakarta: Diva Press

Asrul, dkk. (2015). Evaluasi Pembelajaran. Bandung: Citapustaka Media.

Badar, T. (2017). Mendesain Model Pembelajaran Inovatif, Progresif dan Kontekstual. Jakarta: PT Kharisma Putra Utama.

Daryanto. (2010). Evaluasi Pendidikan. Jakarta: Rinaka Cipta.

Djumingin, S. (2016). Perencanaan Pembelajaran Bahasa, Sastra Indonesia dan Daerah: Teori dan Penerapannya. Makassar: Badan Penerbit Universitas Negeri Makassar.

Heinich, R. (1982). Instructional Media and The New Technologies of Instruction. New York: John Wiley \& Sons, Inc.
Mahsun. (2014). Teks dalam Pembelajaran Bahasa Indonesia Kurikulum 2013. Jakarta: PT Rajagrafindo Persada.

Maleong, L.J. (2017). Metodologi Penelitian Kualitatif. Bandung: PT Remaja Rosdakarya.

Nurdyansyah. (2016). Inovasi Model Pembelajaran Sesuai Kurikulum 2013. Sidoarjo: Nizamia Learning Center.

Sugiyono. (2015). Metode Penelitian Pendidikan (pendekatan kuantitatif, kualitatif, dan $R \& D$ ). Bandung: ALFABETA.

Syam. C. (2011). Buku Ajar Metodologi Penelitian Sastra. Pontianak: Program Studi Pendidikan Bahasa dan Sastra Indonesia.

Wajdi, F. (2020). Buku Ajar Perencanaan Pengajaran. Jakarta: Bumi Aksara.

Zuhdan, dkk. (2011). Pengembangan Perangkat Pembelajaran Sains Terpadu Untuk Meningkatkan Kognitif, Keterampilan Proses, Kreativitas serta Menerapkan Konsep Ilmiah Peserta Didik SMP. Yogyakarta: Program Pascasarjana UNY. 